\title{
Eurasian Economic Union: a challenge for EU policy towards Kazakhstan
}

\author{
Agnieszka Konopelko ${ }^{1}$ (D)
}

Received: 4 February 2016 /Revised: 11 April 2017 / Accepted: 17 April 2017 /

Published online: 27 April 2017

(C) The Author(s) 2017. This article is an open access publication

\begin{abstract}
As a top trading partner and the foreign investor in Kazakhstan, attempting to deepen bilateral relations and review its previous policy towards Kazakhstan and the post-Soviet Central Asian region (The post-Soviet Central Asian region unites five former Soviet republics: Kazakhstan, Kyrgyzstan, Tajikistan, Turkmenistan and Uzbekistan) as a whole, the European Union is facing up to a new set of internal and external conditions which affects its approach to the East. One of the crucial determinants taken into account in terms of the European Union policy towards its Kazakh partner derives from the more advanced processes of Eurasian integration created by the Russian Federation. The question is whether the EU will be able to compete or complement the consistent steps of the Russian integration project and whether the EU should move beyond a trade and investment approach and place emphasis on the other strategic areas? The main research objective concentrates on the identification and examination of the relationship between political decisions and the economic ties of Kazakhstan and its main strategic partners. Considering the current geopolitical situation in Ukraine and Central Asia, the new 'EU-Kazakhstan Enhanced Partnership and Cooperation Agreement' will develop more areas targeted at security and stabilization issues. However, the top-down initiatives are only the legal basis of sectorial cooperation, and the intensification of bilateral relations comes from bottom-up cooperation and people-to-people contacts.
\end{abstract}

\section{Introduction}

The Eurasian Economic Union (EAEU) was established on 1 January 2015 and is a new organisation comprising Russia, Kazakhstan and Belarus, the active participants of the Eurasian integration concept. Armenia joined the Union on 2 January 2015 and

Agnieszka Konopelko

a.konopelko@pb.edu.pl

1 Faculty of Management, Department of Economics and Social Sciences, Bialystok University of Technology, O.S. Tarasiuka 2, 16-001 Kleosin, Poland 
Kyrgyzstan on 12 August 2015. In practice, it is the third stage of the Russian concept of Eurasian economic integration in the post-Soviet area. It was established on the basis of the Customs Union of 1 July 2010 and the Single Economic Space of 1 January 2012.

In 2011, Vladimir Putin, in his article in the Izvestia newspaper, stated that 'the Eurasian Union-is an open project' and declared that the organisation welcomed 'other partners to it, particularly CIS member states'. He emphasised that the Eurasian Union, like the European Union, should base on four pillars: free movement of goods, services and capital and also coordination in economic and currency policies (Putin 2011).

Undoubtedly, the subsequent integrational initiatives of Russia were determined by the European Union multilateral programmes in the framework of Eastern policy, such as the European Neighbourhood Policy (ENP 2003) and Eastern Partnership (Eap 2009). One of the main subjects of the Russian Eurasian concept was Ukraine as the 'soft underbelly' of Russia and its window to the West (Wiśniewska 2013).

It is hard to disagree with Jos Boonstra that the Ukraine crisis has strongly affected European Union relations with the Russian Federation in both the post-Soviet area and in the Central Asia region (Boonstra 2015). An equally important issue concerns the situation in Afghanistan after the withdrawal of the NATO-ISAF (North Atlantic Treaty Organization-International Security Assistance Force) troops and the threat of militant Islam in the region. ${ }^{1}$

The European Union is not a key player in the region of Central Asia and cannot compete with Russia, China or the USA in terms of 'hard power' politics. In the name of 'the civilisation of international relations', the EU creates its international role and identity as a normative power based on particular goals and values (Diez 2005; Kavalski 2007), such as peace, freedom, democracy, rule of law, respect for human rights and fundamental freedoms (Manners 2002).

Zhenis Kembayev admits that while Russia creates more institutionalised forms of economic and security cooperation and advanced forms of economic integration, the European Union offers the basic framework of mutual relations based on actual economic benefits but without a clear long-term strategic perspective (Kembayev 2013) and no vision of how to develop its normative power in the region of Central Asia (Kavalski 2007).

Nonetheless, according to Aleksandra Jarosiewicz and Ewa Fisher, due to asymmetric relations and the economic potential of Russia within the Eurasian Economic Union area, Russian-driven integration strengthens bilateral cooperation with Russia only and has deepened political dependence on Russia (Jarosiewicz and Fisher 2015). The Kazakh economy has already experienced the negative consequences of the European Union sanctions against Russia, declining oil prices, higher import tariffs, weakening demand and depreciation of the Russian ruble against the Kazakh tenge. The economic tensions in 2014 and 2015 resulted in a trade war between these two countries.

Critics of the Eurasian integration model note that the main beneficiary of the EAEU will be the Russian Federation, and that it will deepen political dependence of the

\footnotetext{
${ }^{1}$ According to the International Crisis Group, over the past 3 years, approximately 4000 radical Islamic militants have left the Central Asian post-Soviet countries to fight for Islamic State in Syria. International Crisis Group (2015).
} 
member states on Russia and limit their sovereignty. Moreover, such a union does not have to provide regional stabilisation for Russian involvement in conflicts between the former Soviet republics (Konopelko 2014). Closer regional integration raises concerns pertaining to the willingness of the countries involved to open up to the global economy and markets.

On the other hand, Russia's political leaders emphasise that the EAEU is an opportunity for post-Soviet countries to strengthen their bargaining power in developing a common economic space with the European Union in the future; however, currently it is not a subject of detailed discussions.

Some Russian experts suggest that European and post-Soviet integration should not be deemed mutually exclusive. According to Evgeny Vinokurov, regionalism in the former Soviet Union territories could become a step towards integration with the European Union. Moreover, the Customs Union of Belarus, Kazakhstan and Russia could be a more effective and strong partner for the European Union than separate particular countries (Vinokurov 2013), whereas interregional integration would reduce the asymmetries between the EAEU member countries and the European Union (Vielmini 2013).

Recently, Russian researchers and politicians have been promoting a new concept of 'Greater Asia (Eurasia)' from Shanghai to Saint Petersburg instead of the previous idea of 'Greater Europe' from Lisbon to Vladivostok (Trenin 2015). Naturally, it is a consequence of China's deeper involvement in the Central Asian region, mostly in terms of security (The Shanghai Cooperation Organization), energy (the Chinese share in Kazakhstan's oil companies and in one of the largest Caspian oil fields - Kashagan; importing of Kazakh uranium) and the economy. In 2013, a new 'Silk Road Economic Belt' from China through Central Asia and Russia to Europe was announced by the Chinese President Xi Jinping. China will contribute US\$ 40 billion to revitalise land and maritime routes (Shaohui 2015). The Chinese programme provides financial support for infrastructure and international trade development in selected Eurasian countries as well as Kazakhstan.

The Kazakh authorities admit that this is a result of their consequent 'multi-vector' foreign policy of building of good relationships with major powers, and they are far from being at the centre of the so-called 'New Great Game' (Idrissov 2015).

\section{Kazakhstan's involvement in Eurasian integration}

Kazakhstan has participated in various regional and supraregional organisations, most of which were created by the Russian Federation which was recognised by President Nursultan Nazarbayev as the 'closest and historically equal neighbour' of Kazakhstan (Nazarbayev 1997).

The Commonwealth of Independent States (CIS), Russia's first attempt at the reintegration of the post-Soviet space, established in 1991, has proved unable to move its decision-making procedures to the supranational level. The success of CIS integration has been weakened by national fears of losing autonomy in decision-making and by concerns pertaining to distributional imbalances (Hansen 2013). The failure of the CIS project reflected internal divergences and asymmetries between its member countries and the primarily political, economic, population and territorial dominance of Russia. 
The main purpose of President Nursultan Nazarbayev's foreign policy concept as outlined in 1994 was to unite all the CIS republics into a common economic space (Biryukov 2013). The Nazarbayev doctrine of Eurasianism and vision of a future Eurasian Union was based on economic pragmatism, voluntary participation, the absence of ideology, equality and a consensus among all member countries (Mostafa 2013). It should be emphasised that Nazarbayev opted not for political but closer economic Eurasian integration on the basis of the free flow of goods, services, capital, labour force and - in future - coordinated tax and fiscal policies (Vinokurov 2010).

Furthermore, President Nazarbayev supported deeper integration within the Central Asian subregion. In 1994, Kazakhstan, Kyrgyzstan, Tajikistan and Uzbekistan launched the Central Asian Economic Community, which was then transformed in 2002 into the Central Asian Cooperation Organisation (CACO). The major goals of the abovementioned organisations concentrated on a deepening of the international division of labour, an increase in the openness of national economies, the internationalisation of economic activities and the acceleration of scientific and technical progress. The main objectives of CACO were to provide the necessary preconditions for effective cooperation in the political, economic, environmental, cultural, scientific and technical spheres. Due to visible political and economic divergences between the member countries, it has never been an active and dynamic organisation; however, it was an instrument in the reinforcement of Kazakhstan in the post-Soviet space. In 2005, after Russian accession, it joined the Eurasian Economic Community group (Allison 2004; Konończuk 2007).

The Collective Security Treaty Organization (CSTO), based on the Tashkent Treaty of 1992, was initiated in 2002 by Armenia, Belarus, Kazakhstan, Kyrgyzstan, Russia, Tajikistan and Uzbekistan (Collective Security Treaty Organization).

CSTO is the main military alliance in the CIS space. The Treaty has not developed an organisational structure and complex law base; however, it has evolved towards greater institutionalisation. It was designed to address new threats and challenges through a joint military command, a rapid reaction force for Central Asia, a common air defence system and 'coordinated action' in foreign, security and defence policy, in summary to combat external threats (Hansen 2013).

The Shanghai Cooperation Organisation (SCO) was established in 2001 by China, Kazakhstan, Kyrgyzstan, Russia, Tajikistan and Uzbekistan on the basis of the 'Shanghai Five' formed in 1996. The organisation focused on security and military dimensions such as the enhancement of trust resources in military issues in border areas, reciprocal reduction of military forces in border area, combating international terrorism, extremism and separatism (Shanghai Cooperation Organization). Unlike CSTO, a new model of cooperation based on the 'Shanghai Spirit', with respect to diversified civilisations, relies on informal, less legalistic regulations, multilateral discussions and the exchange of opinions (Aris 2009; Nikitina 2011). However, Russia and China have sought to use the SCO as a macroregional balancing mechanism against the USA and NATO (Allison 2004).

In 2000, Belarus, Kazakhstan, Kyrgyzstan, Russia and Tajikistan launched the Eurasian Economic Community (EurAsEC), a regional group that has ensured multilateral economic cooperation among its member states. Uzbekistan joined EurAsEC in 2005. During the meeting in 2006, the heads of the member states made a decision to establish a Customs Union within the EurAsEC framework, with Belarus, Kazakhstan and Russia as initial members (Eurasian Economic Community). 
It is underlined that EurAsEC (supported by Eurasian Development Bank) is one of the most effective regional organisations in the post-Soviet space, because it is not only concentrated on institutions and formal cooperation but also on financial and economic sectorial projects (Libman 2011). The greatest benefits are visible in Russian and Kazakh investments and Uzbek export markets for its gas, cotton, metal and agriculture products.

The President of the Republic of Kazakhstan, Nursultan Nazarbayev, initiated and consistently supported the process of closer economic integration in Eurasia on the basis of a Customs Union between Russia, Kazakhstan and Belarus.

The first idea for the Customs Union arose in 1995 when Belarus, Kazakhstan and Russia signed the Agreement on the Customs Union and further cooperation agreements. However, in practice, the treaty remained virtual only (Vinokurov 2010; Yeliseyeu 2013).

The Customs Union linking three EurAsEC members, finally launched in 2010 and started in 2011, was supposed to be merely the first step towards closer integration, in the form of the Single Economic Space and Eurasian Economic Union. Hence, the Single Economic Space was formally initiated in 2012 by Belarus, Kazakhstan and Russia (Wiśniewska 2013).

It should be underlined that the mutual benefits of the previous integration initiatives were asymmetric. In the political dimension, the main beneficiary Russia strengthened its position in the post-Soviet region. In the economic area, in spite of an increase in total intraregional trade, the mutual trade exchange remains unbalanced. Only Russia noted a positive balance in trade (Świeżak 2013). Apart from preferential conditions for the import of means of transport, furniture and pharmaceuticals, and due to the implementation of the Russian tariff as a common external tariff, the Common Custom Tariff caused an increase in average Kazakh custom tariff. ${ }^{2}$ Moreover, non-tariff measures (such as phytosanitary and sanitation conditions and technical barriers) still limit trade (United Nations Statistics Division 2016), whereas the EU and China's imports to Kazakhstan were partially replaced by lower quality imports from the Russian Federation.

In 2011, the Presidents of Belarus, Kazakhstan and Russia signed an agreement on the creation of the Eurasian Economic Union for 2015. The official agreement was signed on 29 May 2014. It was supposed to be a counterweight to the European Union and would be based on the Customs Union and Single Economic Space. The core of the future EAEU will comprise Russia and the Central Asian republics (Eurasian Economic Commission 2013). Following the Armenian and Kyrgyz accession to the EAEU, Tajikistan is the next potential member, although these three countries would play a marginal role during the integration process.

Regardless of the presidential declarations of the 'multi-vector', balanced and pragmatic foreign policy and the current economic tensions between Moscow and Astana, President Nazarbayev outlined in 'Kazakhstan's Foreign Policy Concept for 2014-2020' his foreign policy's priority goal of strengthening relations with the Russian Federation and further Eurasian economic integration ('Kazakhstan's Foreign Policy Concept for 2014-2020' 2014). In his annual Address to the People of Kazakhstan in 2005, Nursultan Nazarbayev confirmed that regional integration will

\footnotetext{
${ }^{2}$ Russia's average tariff of $9.7 \%$ is higher than other post-Soviet countries, such as Armenia- $3.5 \%$, Kazakhstan-9.1\% and Kyrgyzstan-4.6\% (World Trade Organization).
} 
provide 'stability, regional progress, and economic, military and political independence' (Nazarbayev 2005). Nonetheless, in line with his Eurasian vision:

Kazakhstan will not be part of organizations that pose a threat to our independence ... The Eurasian Union should be based on: economic pragmatism, voluntary participation of member countries, equality, mutual respect for sovereignty and independence (Nazarbayev 2011).

\section{Kazakhstan's economic relations with the European Union}

Kazakhstan, as the richest and most developed country in the region, has the most complex relationship with globalisation, but even there the anxieties of losing autonomy have limited the degree of openness of its dynamic economy.

The European Union is one of the largest trading and import partners of the Central Asian countries, next to China and Russia. Kazakhstan borders Russia and China and sustains strong relations with both sides, but the EU has become Kazakhstan's preeminent trading partner and first foreign investor. In 2014, Kazakhstan's total trade with the European Union reached more than $€ 30$ billion (more than US\$52 billion). In 2015, bilateral trade exceeded $€ 22$ billion, having decreased by $€ 8$ billion. The European Union recorded a trade deficit of $€ 10$ billion with Kazakhstan. In 2016, EU-Kazakhstan trade reached nearly $€ 18$ billion. Mineral (petroleum) products made up $84.8 \%$ of total Kazakh exports to the European Union. In 2015, the share of the European Union in total Kazakh exports amounted to over $46.7 \%$ and the EU share in total Kazakh trade reached 33.8\% (European Commission. Directorate-General for Trade 2016). Over the years, Kazakhstan's export to the European Union has been limited to a few commodities such as metals and crude oil. Similarly, the structure of the EU exports to Kazakhstan is based on machinery and transport equipment and chemical products.

The European Union as a whole is the first foreign investor in Kazakhstan, and more than half of total gross foreign direct investment (FDI) in Kazakhstan has come from European Union countries. From 1993 to the first quarter of 2014, the inflow of direct investments from the EU to Kazakhstan amounted to US\$ 92.7 billion. In comparison, between 1993 and 2012, inflows of direct investments from the EU countries amounted to about US\$ 70 billion, while Russian investments totaled only about US\$ 6 billion which was more than ten times lower than that of the EU (National Bank of Kazakhstan 2015). Over the period of 2005-third quarter of 2016, the largest foreign direct investors in Kazakhstan came from the Netherlands (US\$ 69.7 billion), the USA (US\$ 26 billion), Switzerland (US\$ 16.7 billion), China (US\$ 13.8 billion), France (US\$ 13 billion), UK (US\$ 12 billion) and Russia (US\$ 10.1 billion). However, the analysis of the structure of largest foreign direct investments in Kazakhstan shows that some of them result of the multinational cooperation, for example Iveco, Royal Dutch Shell, BASF (Invest in Kazakhstan 2017). In the 2016 Report on Monitoring and Analysis of Direct Investments in EAEU and Eurasia, performed by the Eurasian Development Bank Centre for Integration Studies, the role of the Netherlands is defined as a 'trans-shipping destination' for the CIS (mostly Russian, Ukrainian and Kazakh) transnational companies to invest in third countries (Eurasian Development 
Bank Centre for Integration Studies 2016). It should be noted that more than $60 \%$ of the Russian FDI is directed to Cyprus, the Netherlands, Switzerland and the British Virgin Islands.

The Chinese FDI presence in Kazakhstan has been gradually growing in the energy (oil) and transportation sectors. Moreover, in 2015, China, under its 'One Belt, One Road' project ('New Silk Road'), announced to launch 52 new investment projects in frames of Sino-Kazakh Investment Programme towards the non-energy sectors (Eurasian Development Bank Centre for Integration Studies 2016).

Two thirds of the EU investment is directed towards the exploration and extraction of natural resources (mainly oil, gas and metals). Undoubtedly, the energy sector plays a crucial role in bilateral relations between Kazakhstan and the European Union.

Kazakhstan remains the third largest non-OPEC (Organization of the Petroleum Exporting Countries) supplier of energy to the EU, behind Russia and Norway. In 2014, the Kazakh share made up $6.4 \%$ of total EU imports of crude oil (European Commission 2016). According to Nursultan Nazarbayev, the President of Kazakhstan,

bilateral cooperation in this field will increase in the future, as European companies participate in the exploration of the Kashagan oil field, the largest in the Caspian Sea (Nazarbayev 2014).

Jose Manuel Barroso, the former President of the European Commission, confirmed that Kazakhstan is an

important and reliable energy partner for the EU and the new bilateral Partnership and Cooperation Agreement will enhance mutual cooperation in the energy sector and moves beyond WTO and Energy Charter Treaty commitments (Barroso 2014).

Kazakhstan is one of the beneficiary countries of the EU 'Transport Corridor Europe-Caucasus-Asia' (TRACECA) programme launched in 1993 to develop a multimodal transport corridor from Europe to China. The programme supported economic development and regional cooperation among the partner countries. The European Union assigned more than $€ 180$ million to more than 80 projects on infrastructure development, legal harmonisation, logistics, trade facilitation and motorways, civil aviation and maritime transport safety and security (European Commission, International Cooperation and Development 2015).

\section{The European Union response to enhanced Eurasian integration}

Eurasian Economic Union unites five member states of the same post-Soviet area and legacy but different subregional conditions and visible divergence of particular interests. European Union policy towards the EAEU participants develops in different ways, as well. Four out of five EAEU member countries have been included into multilateral dimension of the EU foreign policy. Armenia and Belarus are covered by the European Neighbourhood Policy and the EU's Eastern Partnership initiative. In turn, Kazakhstan and Kyrgyzstan are included into the EU Strategy for Central Asia. At bilateral level, 
European Union concluded Partnership and Cooperation Agreements with all members of the EAEU; however, the ratification of the PCA with Belarus was suspended in 1997 (Delegation of the European Union to Belarus 2016).

Since 2010, Armenia, as Georgia, Moldova and Ukraine, had negotiated EU Association Agreements with the European Union including a Deep and Comprehensive Free Trade Area (DCFTA), but in the end, unlike Georgia, Moldova and Ukraine, Armenia failed to initial the agreement. In 2013, when Armenia declared its intention to join the Customs Union of Russia, Belarus and Kazakhstan and then to participate in the EAEU, the European integration process of Armenia including the signature of the EU Association Agreement halted. (Czerewacz-Filipowicz and Konopelko 2017). Nonetheless, in 2014, Armenia was granted the GSP+ status on preferences of custom tariffs. In terms of regional cooperation, Armenia benefits from the ENP financial instruments for justice and public administration reforms, private sector development, cross-border and Erasmus mobility projects (€281.5 million in 2007-2013). In the framework of the EU-Armenia bilateral Partnership and Cooperation Agreement, cooperation of the common Council and Committee concentrates on political and human rights dialogue, trade, transport, environment and cultural areas (Delegation of the European Union to Armenia 2016).

In 2009, Belarus joined the EU Eastern Partnership Programme. It participated mostly in the multilateral track of the initiative, with the only exception on bilateral track being the Visa-Facilitation and Readmission Agreement. In 2007-2013, the EU allocated to Belarus $€ 94.2$ million for regional projects (European Union External Action Service 2015). Recently, European Council decided to enhance EU-Belarus economic sectoral cooperation (in trade and energy); however, over the years, the political situation in Belarus expressed the EU concerns over violations of human and civil rights and the rule of law. In retaliation for President Lukashenko repression, the Partnership and Cooperation Agreement with Belarus signed in March 1995 has not been ratified. Moreover, the EU existing sanctions against Belarus have been gradually extended (European Council 2016).

Similarly, the political climate around the Russian Federation influenced the progress in implementation of the Partnership and Cooperation Agreement with European Union. Practically, since 2010, negotiations on the renewed bilateral EU-Russia agreement were frozen. Thus, the EU-Russia Partnership for Modernisation remains the major platform of bilateral cooperation. The Ukrainian crisis results in trade war between the both sides especially in terms of imposing sanctions and counter-sanctions. Nonetheless, Russia remains one of the largest EU's trade partners and the EU's suppliers of oil and gas (with high share of Ukrainian transit). However, the EURussia energy dialogue and negotiations to enhance the energy security and increase the energy efficiency remain under way (European Union External Action Service 2016). Russia is not a participant of the ENP; however, it participates in Cross-Border Cooperation, the Erasmus Mundus programme and the EU-Baltic Sea Programme under the European Neighbourhood and Partnership Instrument (ENPI). Furthermore, in 2007-2013 the ENPI bilateral assistance to Russia totaled €66.5 million (European Neighbourhood and Partnership Instrument 2014).

The development of the EU cooperation with Kazakhstan has played an important role since that nation's independence in 1991 and especially since President Nazarbayev has received delegation of the European Commission (Byrne 2014). 
More than 300 projects amounting to $€ 140$ million have been funded in support of Kazakhstan's development, the implementation of socioeconomic reforms, and in support of EU-Kazakhstan relations and people-to-people contacts.

At multilateral level, within the auspices of 'The EU and Central Asia: Strategy for a New Partnership' (Council of the European Union 2007), bilateral cooperation with the countries of Central Asia has concentrated on the reduction of poverty, the improvement of living standards, good governance and economic reformation (European Commission 2011).

The first Central Asia Multi-annual Indicative Programme 2007-2010 based on the Development Cooperation Instrument allocated $€ 44$ million for bilateral programmes with Kazakhstan. The second Multi-annual Indicative Programme allocated $€ 30$ million for the period from 2011 to 2013. The largest amount of EU financial assistance was directed to the poorest countries in the region: Kyrgyzstan (respectively $€ 55$ and $€ 51$ million) and Tajikistan (respectively $€ 66$ and $€ 62$ million). Priority areas for cooperation included the modernisation of the public sector and local development, judicial reform, economic diversification and promotion of the private sector (European Commission 2006, 2010).

However, it should be emphasised that implementation of the EU Central Asia Regional Strategy was somewhat slow (especially in Turkmenistan and Uzbekistan). According to the European Court of Auditors,

the regional programmes did not achieve a genuine regional dimension; a significant share consisted merely of 'multi-country' facilities available to each partner country individually (European Court of Auditors 2013).

They recommend that the design of any future regional programmes should achieve a real regional dimension and concentrate on a smaller number of sectors, thus improving the design of programmes in terms of administrative costs, anti-corruption mechanisms and changing circumstances. At the end of 2012, $60 \%$ of overall planned commitments for the 2007-2012 period under the Development Cooperation Instrument-Asia had been contracted in Kazakhstan and 73\% in Kyrgyzstan while only $28 \%$ paid in Kazakhstan and $45 \%$ in Kyrgyzstan (European Court of Auditors 2013).

Nevertheless, it should be noted that the strategy intensified mutual relations and EU engagement in Central Asia, especially in terms of political and human rights dialogue, democratic reforms (for example under the European Instrument for Democracy and Human Rights), energy dialogue, education cooperation and diplomatic presence. However, as we may observe, no remarkable progress was made in the democratisation of the political regime and protection of political rights and civil liberties.

In 2011-2016, the Freedom House reports 'Freedom in the World' and 'Nations in Transit' classified Kazakhstan as an authoritarian regime with 'Not free' freedom status. The Freedom House ratings are based on scores allocated in the categories of democracy score, freedom status, civil liberties, corruption and political rights. The ratings are based on a scale of 1 to 7, with 1 representing the highest level of democratic progress and 7 the lowest. Kazakhstan's government did not succeed in implementing democratic reforms (6.61). Despite gaining the chairmanship of the OSCE in 2010, the Parliament failed to pass any substantive amendment to limit the authoritarian system 
and the power of the president. The constitution grants the president considerable control over the legislature, the judiciary and local governments. Constitutional changes removed term limits for Nazarbayev opening the possibility of a lifetime presidency (6.75). Elections to Parliament took place without any opposition candidates (6.75) (Freedom House 2016).

According to the Transparency International 'Corruption Perceptions Index 2016', in 2016, Kazakhstan was ranked 131st out of 176 assessed countries and territories (Transparency International 2016). Although the Kazakh ranking is higher than other Central Asian countries, corruption in the country is widespread at all levels of government and the judicial system. The nepotistic practices of the president are prominent in business and government. Judges, who are underpaid, are subject to bribery, and corruption is evident throughout the judicial system. Such mechanisms make foreign financial assistance inefficient.

It should be underlined that the countries of Central Asia (including Kazakhstan) perceive democratic rules as a threat to their stability, which is why, according to Jos Boonstra, they are 'more comfortable with Russia's model of authoritarian governance' (Boonstra 2015).

According to the Human Rights Watch, in 2014, Kazakh authorities following adoption of a new law limited fundamental political and human rights, such as freedom of speech and freedom of press, freedom of religion and freedom of assembly (Human Rights Watch 2015).

Further governmental restrictions, including criminal charges, hit non-governmental organisations (NGOs), religious movements, the peaceful protesters against land reforms, independent journalists and media outlets. In March 2016, European Parliament in its resolution on Freedom of Expression in Kazakhstan stated 'the serious deterioration of the climate for media and free speech' and called the Kazakhstan's authorities to review legislation (Human Rights Watch 2017).

Both sides of the EU-Kazakhstan Human Rights Dialogue declared their readiness to cooperate on civil society development and promotion of human rights and democratic values; however, in practice, the Kazakh authorities rejected recommendations of European Union, the United Nations (UN) and the Organization for Security and Cooperation in Europe (OSCE) on violations of human rights in 2014 using their own selective interpretation of universal principles (Open Dialog Foundation 2015).

With the second Action Plan on Human Rights and Democracy 2015-2019, the European Union confirmed its involvement in the protection and promotion of human rights and democracy in the world. Mostly, it will be focused on support for the national institutions responsible for ensuring respect for human rights and liberties in all areas of its external action (European Commission 2015).

Within the new financial budget of 2014-2020, the European Union provides more than $€ 1$ billion to support the Central Asian countries on the basis of the regional and bilateral allocations. The financial assistance will be addressed mainly to Kyrgyzstan ( $€ 184$ million for security, energy, water, environment), Tajikistan (€251 million for education, health, rural development, local governments and civil society projects) (European Commission 2013). Moreover, Kyrgyzstan and Tajikistan are covered by the EU's Generalised System of Preferences (GSP) in access to its market. Furthermore, in 2016, Kyrgyzstan was granted the GSP+ status on preferences of customs tariffs (Delegation of the European Union to the Kyrgyz Republic 2016). In line with the 
principles of the Agenda for Change, Kazakhstan is one of the countries which has 'graduated' and has been considered as an upper middle-income country. Thus, Kazakhstan, Uzbekistan and Turkmenistan will benefit only from regional and thematic programmes. Funding will be allocated to improve the regional management of natural resources, social and economic development as well as regional security (European Commission 2013).

Still, according to the European Commission 'Multiannual Indicative ProgrammeRegional Central Asia 2014-2020', regional cooperation:

plays a central role for approximation and cooperation processes also within the wider region including the possible participation of Central Asian partners in ENP East regional or South-Asia cooperation programmes (European Union External Action Service 2013).

In 2014-2020, indicative allocations for the Central Asia Regional Indicative Programme will reach $€ 245$ million, of which $€ 170$ million has been earmarked for Sustainable Regional Development, €37.5 million for Regional Security for Development, €35 million for a Multi-country Technical Assistance Facility and €2.5 million for support measures. An additional allocation of $€ 115$ million will be provided for the ERASMUS+ educational programme (European Union External Action Service 2013).

In a newly proposed EU Partnership Instrument 'First Multi-annual Indicative Programme during 2014-2017', the countries of Central Asia were recognised as one of the strategic partners of the European Union. The EU's interests are mainly focused on transregional challenges, such as energy, environment and socioeconomic development, illicit trafficking of human beings and substances, organised crime and terrorism. The programme is to be complementary to other EU external instruments, such the European Neighbourhood Policy and the Eastern Partnership. The EU Partnership Instrument towards Russia concentrates not only on the top-down support for the EU-Russia Partnership for Modernization but also on the bottom-up relations with civil society organisations to promote the EU's values and interests (European Commission 2014).

At bilateral level, in 1999, the European Union and Kazakhstan concluded a 'Partnership and Cooperation Agreement' (PCA). The PCA with Kazakhstan provided a framework for political dialogue. It set the principal common objectives in terms of promotion of trade and investment, sustainable development, economic, social, financial, civil, scientific, technological and cultural cooperation, legal approximation and support for Kazakhstan's efforts to consolidate its democracy, develop its economy and complete its transition to a market economy (European Union External Action Service 1999). Despite a number of objectives set out in the agreement, the document has not unfolded the broad perspectives and specific offer of closer cooperation as in the case of the Eastern Partnership countries and the Russian Federation.

The new 'EU-Kazakhstan Enhanced Partnership and Cooperation Agreement' was initialled in Brussels on January 20, 2015, while on December 21, 2015, Federica Mogherini, High Representative of the European Union for Foreign Affairs and Erlan Idrissov, Minister of Foreign Affairs of the Republic of Kazakhstan finally concluded the new agreement. This agreement replaced the Partnership and Cooperation 
Agreement which has been in force since 1999. The new PCA focuses on democratic principles and the rule of law, human rights and fundamental freedoms and sustainable development (European Union External Action Service 2015). The main priorities of the Agreement should be perceived positively; however, Kazakhstan still remains under a consolidated authoritarian political regime.

Aside from the stronger political and economic mutual relations, the new Enhanced Partnership and Cooperation Agreement places emphasis on increasing bilateral trade, investment, energy and services. However, the Agreement does not provide comprehensive free trade area as DCFTA agreements concluded by the EU and Georgia, Moldova and Ukraine (International Institute for Applied System Analysis 2016). New PCA Agreement encompasses 29 different areas, such as innovation, science, education, transport, environment, culture, education and social issues and gives greater consideration to shared security threats, especially in the context of the NATO-ISAF troop withdrawal and the threat of the so-called Islamic State (Nazarbayev 2014).

According to Traian Hristea, the Head of the European Union Delegation to Kazakhstan, the new Enhanced Partnership and Cooperation Agreement will strengthen political and economic relations between the EU and Kazakhstan and will contribute to Kazakhstan's political and social development and the economic diversification (Delegation of the European Union to Kazakhstan 2015). It is hard to disagree with such opinion; however, this wide combination of economic, political, social and cultural issues raises concerns about effectiveness of the implementation of particular objectives and programmes outlined in the new PCA.

Currently, there is no formal institutional cooperation between two regional blocks, the EU and the EAEU. The closer cooperation with the EU could be complementary path to the dominant Chinese and Russian position and influence in the region of Central Asia. Furthermore, in view of the creation of the EAEU and the European Neighbourhood Policy together with the Eastern Partnership, an intensification of multilateral (interregional) relations in Eurasia (beyond geographical approach) would be profitable for all sides. ${ }^{3}$ A good example of such sectoral cooperation is Memorandum on mutual cooperation in transport signed in November 2016 by the GUAM organisation and participants of the TRACECA initiative (TRACECA 2016).

Furthermore, the UE should strive for its inclusion into the new 'One Belt, One Road' (including 'Silk Road Economic Belt') project. Most of the European cargo to China (90\%) has been provided by shipping and air freight. Trilateral economic sectoral cooperation (in transport, infrastructure, energy) between three institutional regional projects, the EU, the EAEU and the 'One Belt, One Road', would place more emphasis on Central Asian countries in geostrategic region and balance a dominant economic position of China in Eurasia.

In a long-term perspective, once all EAEU members join the WTO, the EU and the EAEU could negotiate on a deep and comprehensive free trade area. So far, both sides have concluded trade agreements with individual countries (for example Canada, Singapore, Vietnam). The analysts of the International Institute for Applied System Analysis and the Eurasian Development Bank suggest the 'comprehensive nature' of

\footnotetext{
${ }^{3}$ In 2015, European Commission President Jean-Claude Juncker suggested the possibility of closer relations between the EU and the EAEU but only after fulfilment of the Minsk II ceasefire agreement (Duchâtel et al. 2016).
} 
mutual relations between two regional groupings both at institutional and economic levels. Undoubtedly, such deeper integration would be beneficial for the Kazakhstan's economy and the society (International Institute for Applied System Analysis 2016). Currently, such vision seems unrealistic for the visible divergences in perception of the geopolitical role of particular actors in Eurasian area, therefore different approaches to existing international conflicts in post-Soviet space and different approaches to understanding democratic principles and law regulations.

\section{Conclusions}

The main pivotal relations between Kazakhstan and Russia concentrate on integration processes in the framework of the Customs Union, Single Economic Space and Eurasian Economic Union. Unlike the Russian political approach, Kazakhstan treats Eurasian integration as an economic project and does not wish to be involved in geopolitical gamesmanship (as in cases of Georgia and Ukraine). Kazakhstan's leaders have argued against the transformation of economic projects into matters on the level of political integration with the dominant role of Russia. Such a form of integration becomes contradictory to Nazarbayev's policy of strengthening Kazakhstan's sovereignty and its independent role on the international stage ('multi-vector' foreign policy). ${ }^{4}$ Kazakhstan has contested the Russian proposal within the Customs Union for a significant increase of customs duty imposed on goods imported from the nonunion countries and non-tariff measures. Furthermore, the Kazakh economy has already experienced the negative impact of European Union sanctions against the Russian Federation and Russia and Kazakhstan's 'trade war'.

To deepen bilateral relations and irrespective of the EU sanctions against the Russian Federation, Kazakhstan launched a visa-free regime with 12 countries of the European Union that are key investors in Kazakhstan and may introduce new technologies into the country (The Embassy of the Republic of Kazakhstan to the Kingdom of Sweden 2015).

It should be noted that due to the nature of trade, differences in economic potential and the central strategic location of Russia, the aforementioned institutional integration strengthens bilateral economic relations of the post-Soviet countries with the Russian Federation rather than functioning as multilateral equal cooperation within regional agreements.

The European Union is a leading trade partner for the region. There is a mutual desire of the EU and Kazakhstan to enhance economic cooperation, including diversification of trade and the promotion of investment. Undoubtedly, one of the barriers to effective implementation of the assumed objectives results from insufficient financial involvement of European Union in implementing projects. Regardless of the increased EU support by $56 \%$ for the 2014-2020 period, the amount of one billion EUR is incomparably smaller than the funds allocated by China (US\$ 30 billion to the 'Silk

\footnotetext{
${ }^{4}$ Kazakhstan is also engaged in other international projects such as: Shanghai Cooperation Organisation (SCO), Economic Cooperation Organization (ECO), Collective Security Treaty Organization (CSTO), Organization of Islamic Cooperation (OIC) and Organization for Cooperation and Security in Europe (OSCE).
} 
Road Economic Belt' and the 'Maritime Silk Road') and Russia (US\$ 10 billion to the anti-crisis fund).

The EU strategy for Central Asia has confirmed its willingness to enter into an open and constructive dialogue with regional organisations in Central Asia and to establish regular contacts. Similarly, President Nazarbayev has expressed that the Eurasian Economic Union should be more engaged in the enhancement of interregional cooperation, and Kazakhstan should be involved in world economic ties. The recent steps confirm the Kazakh choice to integrate with the global economy. On 27 July 2015, members of the World Trade Organization (WTO) formally approved Kazakhstan's WTO membership terms, and at the end of 2015, it became the 162nd WTO member (World Trade Organization 2015).

It should be emphasised that the current European Union strategy towards Central Asia outlines too great a number of areas and objectives. It is arguable whether the European Neighbourhood Policy should be extended directly to Kazakhstan and the other republic of Central Asia as 'neighbours of neighbours'. Likewise, in terms of the individual approach in the Eastern Partnership towards Eastern Europe and the South Caucasus countries, the EU should focus on bilateral relations with the particular countries of Central Asia. The new enhanced Partnership and Cooperation Agreements should be tailored individually and should consider special conditions, needs and interests. Primarily, it should move beyond the economic approach (Border Management in Central Asia-BOMCA and Central Asia Drug Action ProgrammeCADAP are examples of good coordinated and implemented projects). Bottom-up trade and investment relations have been increasing irrespective of the top-down integration initiatives, while progress in terms of democratisation processes has not been achieved. Wider support for civil society organisations to increase people-topeople contacts (cooperation of business chambers, students and academics and cooperation between non-governmental organisations), the development of common rules, and the promotion of democracy and transparency should be one of the main priorities of both the renewed EU strategy as a core instrument of its normative approach in the region of Central Asia and its bilateral partnership and cooperation with Kazakhstan. Thus, Kazakhstan could be a leader partner in promotion of the EU democratic reforms, good governance and common values in the Central Asian region.

Acknowledgements The project was financed by founds of National Science Center based on the number of decision DEC-2011/03/B/HS4/05930.

Open Access This article is distributed under the terms of the Creative Commons Attribution 4.0 International License (http://creativecommons.org/licenses/by/4.0/), which permits unrestricted use, distribution, and reproduction in any medium, provided you give appropriate credit to the original author(s) and the source, provide a link to the Creative Commons license, and indicate if changes were made.

\section{References}

Allison R (2004) Regionalism, regional structures and security management in Central Asia. Int Aff 80(3):474 Aris S (2009) A new model of Asian regionalism: does the Shanghai Cooperation Organisation have more potential than ASEAN? Camb Rev Int Aff 22(3):457 
Barroso JM (2014) Statement by President Barroso following his meeting with Mr Nursultan Nazarbayev, President of Kazakhstan. http://europa.eu/rapid/press-release_SPEECH-14-675_en.htm. Accessed 14 July 2015

Biryukov S (2013) Eurasian Doctrine of Kazakh President Nursultan Nazarbayev: "Thinking space". Geopolitics 24.01.2013. http://www.geopolitica.ru/en/article/eurasian-doctrine-kazakh-presidentnursultan-nazarbayev-thinking-space\#.VqDjj1nzjuo. Accessed 4 Jan 2016

Boonstra J (2015) Reviewing the EU's approach to Central Asia. EUCAM No. 34. http://www.eucentralasia. eu/uploads/tx_icticontent/EUCAM-PB-34-Reviewing-EU-policies-in-Central-Asia-EN_01.pdf. Accessed 20 June 2015

Byrne S (2014) Legal framework of independence. European dialogue. http://eurodialogue.eu/LEGAL\%20 FRAMEWORK\%20OF\%20INDEPENDENCE. Accessed 20 Dec 2015

Collective Security Treaty Organization. http://www.odkb.gov.ru/start. Accessed 4 Jan 2016

Council of the European Union (2007) The EU and Central Asia: strategy for a new partnership. Brussels 10113/07

Czerewacz-Filipowicz K, Konopelko A (2017) Regional integration processes in the Commonwealth of Independent States Area. Economic and political factors. Springer

Delegation of the European Union to Armenia (2016) Armenia and the EU. https://eeas.europa. eu/delegations/armenia/896/armenia-and-eu_en. Accessed 28 Mar 2017

Delegation of the European Union to Belarus (2016) EU-Belarus relations, fact sheet. https://eeas.europa. eu/delegations/belarus/4014/eu-belarus-relations-fact-sheet en. Accessed 28 Mar 2017

Delegation of the European Union to Kazakhstan (2015) New Head of the EU Delegation to Kazakhstan Traian HRISTEA presents his credentials to President Nursultan Nazarbayev. http://eeas.europa. eu/delegations/kazakhstan/press corner/all news/news/2015/20151028 en.htm. Accessed 2 Nov 2015

Delegation of the European Union to the Kyrgyz Republic (2016) Kyrgyz Republic and the EU. https://eeas. europa.eu/delegations/kyrgyz-republic/1397/kyrgyz-republic-and-eu_en. Accessed 29 Mar 2017

Diez T (2005) Constructing the self and changing others: reconsidering normative power Europe. Millennium 33:617

Duchâtel M et al (2016) Eurasian integration: caught between Russia and China, European Council on Foreign Relations. http://www.ecfr.eu/article/essay_eurasian. Accessed 15 Mar 2017

Eurasian Development Bank Centre for Integration Studies (2016) Monitoring and analysis of direct investments in EAEU and Eurasia. Report 41: 27, 42, 57

Eurasian Economic Commission (2013) Eurasian Economic Integration. Facts and figures. http://eurasiancommission.org/ru/Documents. Accessed 10 Jan 2016

Eurasian Economic Community. http://www.evrazes.com/en/about. Accessed 8 January 2016

European Commission (2006) Central Asia Development Cooperation Instrument Indicative Programme 2007-2010. http://eeas.europa.eu/central_asia/rsp/nip_07_10_en.pdf. Accessed 7 Sept 2015

European Commission (2010) Central Asia Development Cooperation Instrument Indicative Programme 2011-2013. http://www.eeas.europa.eu/central_asia/docs/2010_ca_mtr_en.pdf. Accessed 7 Sept 2015

European Commission (2011) European Union-Central Asia Deveeuropa.eu/europeaid/infopoint/publications/europeaid/documents/263a_en.pdf. Accessed 7 Sept 2015

European Commission (2013) EU announces future commitments for development with Central Asia Region. http://ec.europa.eu/commission_2010-2014/piebalgs/index_en.htm. Accessed 9 Sept 2015

European Commission (2014) First Multi-annual Indicative Programme for the period 2014-2017. http://ec. europa.eu/dgs/fpi/documents/pi_mip_annex_en.pdf. Accessed 29 Mar 2017

European Commission (2015) EU Action Plan on Human Rights and Democracy. Brussels. 28.4.2015 JOIN 16 final

European Commission (2016) EU energy in figures. https:/ec.europa.eu/energy/sites/ener/files/documents/ pocketbook_energy-2016_web-final_final.pdf. Accessed 28 Mar 2017

European Commission, International Cooperation and Development. https:/ec.europa.eu/europeaid/regions/ central-asia/eu-support-transport-development-central-asia_en. Accessed 12 Oct 2015

European Commission. Directorate-General for Trade (2016) European Union, Trade in goods with Kazakhstan. http://trade.ec.europa.eu/doclib/docs/2006/september/tradoc_113406.pdf. Accessed 2 Apr 2017

European Council (2016) Council conclusions on Belarus. http://www.consilium.europa.eu/en/press/pressreleases/2016/02/15-fac-belarus-conclusions. Accessed 2 Apr 2017

European Court of Auditors (2013) EU Development Assistance to Central Asia. Special Report No 13/2013, Luxembourg

European Neighbourhood and Partnership Instrument (2014) https://ec.europa.eu/europeaid/sites/devco/ files/overview_of_enpi_results_2007-2013_en_0.pdf. Accessed 30 Mar 2017 
European Union External Action Service (1999) The European Union and the Republic of Kazakhstan Partnership and Cooperation Agreement. http://eeas.europa.eu/delegations/kazakhstan/documents/eu_ kazakhstan/pca_kazakhstan_en.pdf. Accessed 16 Aug 2015

European Union External Action Service (2013) Multiannual indicative programme. Regional Central Asia 2014-2020. http://ec.europa.eu/europeaid/sites/devco/files/mip-2014-2020-central-asia-regional20140812-en.pdf. Accessed 9 Sept 2015

European Union External Action Service (2015) EU-Kazakhstan sign Enhanced Partnership and Cooperation Agreement. http://eeas.europa.eu/statements-eeas/2015/151221_02_en.htm. Accessed 3 Jan 2016

European Union External Action Service (2016) The Russian Federation and the European Union. https://eeas.europa.eu/headquarters/headquarters-homepage/720/russian-federation-and-european-unioneu_en. Accessed 29 Mar 2017

Freedom House (2016) Freedom in the World 2016. Kazakhstan. Nations in Transit 2016. Kazakhstan. https://freedomhouse.org. Accessed 25 Mar 2017

Hansen FS (2013) Integration in the post-Soviet space. Int Area Stud Rev 16(2):146-148

Human Rights Watch (2015) World Report 2015: Kazakhstan. https:/www.hrw.org/world-report/2015/countrychapters/kazakhstan. Accessed 10 Dec 2015

Human Rights Watch (2017) World Report 2017: Kazakhstan. https://www.hrw.org/world-report/2017/countrychapters/kazakhstan. Accessed 30 Mar 2017

Idrissov E (2015) The great gain not the great game: how Kazakhstan is charting its own course in the world. European Dialogue. http://www.eurodialogue.eu/The\%20great\%20gain\%20not\%20the\%20great\%20 game $\% 3 \mathrm{~A} \% 20 \mathrm{How} \% 20 \mathrm{Kazakhstan} \% 20$ is\%20charting\%20its\%20 own\%20course\%20in \%20the $\% 20$ world. Accessed 4 Jan 2016

International Crisis Group (2015) Syria calling: radicalisation in Central Asia. Europe and Central Asia Briefing $N^{\circ} 72$. http://www.crisisgroup.org/ /media/Files/asia/central-asia/b072-syria-callingradicalisation-in-central-asia.pdf. Accessed 1 Aug 2015

International Institute for Applied System Analysis (2016) Challenges and opportunities of economic integration within a Wider European and Eurasian Space. IIASA Synthesis Report: 8, 15, 28

Invest in Kazakhstan (2017) Foreign direct investments. http://www.investkz.com/en/journals/105/841.html. Accessed 2 Apr 2017

Jarosiewicz A, Fisher E (2015) The Eurasian Economic Union-more political, less economic. Centre for Eastern Studies Commentary No. 157:2-3

Kavalski E (2007) Partnership or rivalry between the EU, China and India in Central Asia: the normative power of regional actors with global aspirations. Eur Law J 13(6):841-842

Kazakhstan's Foreign Policy Concept for 2014-2020 (2014) Kazakh Embassy in Poland. http://www. kazakhstan.pl/index.php?option=com_content\&view=article\&id=1369\%3Akazakhstans-foreign-policyconcept-for-2014-2020\&catid=1\%3Aaktualnoci\&Itemid=33\&lang=pl. Accessed 11 Jan 2016

Kembayev Z (2013) The (In)Compatibility between Regional Integration Processes in the Post-Soviet Area and within the European Neighborhood Policy. Osteuropa-Recht No. 59(4):369-377

Konończuk W (2007) The failure of integration. The CIS and other international organisations in the postSoviet area 1991-2006. Centre for Eastern Studies, Warsaw 38

Konopelko A (2014) Bases and mechanisms of regionalism in post-Soviet Central Asia. International Business and Global Economy No. 33:219

Libman A (2011) Commonwealth of Independent States and Eurasian Economic Community. First International Democracy Report, Centre for Studies on Federalism. http://www. internationaldemocracywatch.org/attachments/460_CIS-libman.pdf. Accessed 8 Jan 2016

Manners I (2002) Normative power Europe: a contradiction in terms? J Common Mark Stud 40(2):7-8

Mostafa G (2013) The concept of 'Eurasia': Kazakhstan's Eurasian policy and its implications. J Eurasian Stud (4):164-165

National Bank of Kazakhstan (2015) Invest in Kazakhstan. http://invest.gov.kz/?option=content\&section=4 \&itemid=75. Accessed 10 Aug 2015

Nazarbayev N (1997) Address of the President of the Republic of Kazakhstan, Nursultan Nazarbayev, to the People of Kazakhstan. http://www.akorda.kz/en/addresses. Accessed 4 Jan 2016

Nazarbayev N (2005) Address of the President of the Republic of Kazakhstan, Nursultan Nazarbayev, to the People of Kazakhstan. http://www.akorda.kz/en/addresses. Accessed 4 Jan 2016

Nazarbayev N (2011) Eurasian Union: from idea to future history, Izvestia News, 28 October 2011

Nazarbayev N (2014) The next chapter in Kazakhstan-EU relations. European dialogue. http://www. eurodialogue.eu/The\%20Next\%20Chapter\%20in\%20Kazakhstan-EU\%20Relations. Accessed 7 July 2015

Nikitina Y (2011) Regional security cooperation in the post-Soviet space. Russ J Int Secur 17(4):49 
Open Dialog Foundation (2015) Kazakhstan rejects statements of the UN, EU and OSCE on violations of human rights. http://en.odfoundation.eu/a/7073,kazakhstan-rejects-statements-of-the-un-eu-and-osce-onviolations-of-human-rights. Accessed 7 Dec 2015

Putin V (2011) Новый интеграционный проект для Евразии - будущее, которое рождается сегодня. Izvestia, 3 October 2011. http://izvestia.ru/news/502761. Accessed 27 Mar 2017

Shanghai Cooperation Organisation. http://www.sectsco.org/EN123/brief.asp. Accessed 4 Jan 2016

Shaohui T (2015) Chronology of China's belt and road initiative. Xinhua News Agency. http://news. xinhuanet.com/english/2015-03/28/c 134105435.htm. Accessed 2 Jan 2016

Świeżak P (2013) The customs union-between an illusion of the "Eastern-European Union" and the spectre of the "New USSR". Natl Secur 28:21

The Embassy of the Republic of Kazakhstan to the Kingdom of Sweden (2015) Factsheet on the visa-free regime. http://www.kzembassy.se/index.php/en/last-news/1929-factsheet-on-the-visa-free-regime. Accessed 15 Sept 2015

TRACECA (2016) Initiative of mutual cooperation between TRACECA and GUAM-a catalyst of the transport dialogue development in the region. http://www.traceca-org.org/en/news/singlenews/n/initiative_of_mutual_cooperation_between_traceca_and_guam_a_catalyst_of_the_transport_ dialogue_d. Accessed 3 Apr 2017

Transparency International (2016) Corruption perceptions index 2016. http://www.transparency. org/news/feature/corruption_perceptions index 2016. Accessed 25 Mar 2017

Trenin D (2015) From Greater Europe to Greater Asia? The Sino-Russian Entente, Carnegie Moscow Center. http://carnegie.ru/publications/?fa=59728\#. Accessed 10 Oct 2015

United Nations Statistics Division. https://unstats.un.org/unsd/methods. Accessed 10 Jan 2016

Vielmini F (2013) The challenges of Eurasian Integration for Kazakhstan. ISPI Anal (151)3

Vinokurov E (2010) The evolution of Kazakhstan's position on relations with Russia in 1991-2010. MPRA Paper No. 22187:3-4. http://mpra.ub.uni-muenchen.de/22187. Accessed 8 Jan 2016

Vinokurov E (2013) Eurasian Integration Yearbook 2013. Eurasian Development Bank, Almaty 15

Wiśniewska I (2013) Eurasian integration. Russia's attempt at the economic unification of the post-Soviet area. Centre for Eastern Studies Working Papers No. 44: 8-9

World Trade Organization (2015) General Council approves Kazakhstan's membership terms, only ratification left. https://www.wto.org/english/news_e/news15_e/acc_kaz_27jul15_e.htm. Accessed 2 Sept 2015

Yeliseyeu A (2013) What Eurasian Integration brings to Belarus. Eastern Europe Studies Centre. Bell Issue 5(35):1 